\title{
MID-HOLOCENE HORIZONS OF STRONGLY DECOMPOSED PEAT AND PROBLEMS OF DATING PALEOHYDROLOGICAL CHANGES IN MIRES IN THE RACIBÓRZ BASIN, SOUTHERN POLAND
}

\author{
KRZYSZTOF J. WÓJCICKI and MALGORZATA NITA \\ University of Silesia, Faculty of Earth Sciences, Będzińska 60, 41-200 Sosnowiec, Poland- \\ KNOW (Leading National Research Centre)
}

Received 16 May 2016

Accepted 24 March 2017

\begin{abstract}
During litho-stratigraphic studies of deposits in small mires in the upper basin of the Oder River, mid-Holocene hiatuses identified by the presence of horizons of strongly decomposed peat (HSDP), were identified at four sites. Radiocarbon dating results indicate long $\left(10^{3}\right.$ years $)$ breaks in peat accumulation and the dates obtained from the underlying layers of deposit are inconsistent with the pollen record. In order to explain these discrepancies, an attempt was made to recreate the conditions of HSDP formation under the influence of endo- and exogenous factors determining peatland productivity. In the light of macrofossil analysis, the development of HSDP during the Atlantic and Subboreal periods, when the humidity of habitats decreased, occurred at an advanced stage of development of swamps with Alnetea glutinosae forest communities. The gradual rise in water levels in the mires that started in the Subboreal period and intensified during the Subatlantic period was recorded as a slow shift in vegetation towards non-forest, sedge-moss communities belonging to the Magnocaricion alliance or the Scheuchzerio-Caricetea nigrae class. One consequence of the mechanism of HSDP formation is the existence of limitations on the dating of the duration of the dry phase owing to the presence of organic matter of different ages in the degraded peat layer. The determination of the age of wet phases offers better prospects. In the light of radiocarbon dating, which is essentially in line with the pollen analysis results, the transition towards positive peatland productivity occurred between $c a$. $9^{\text {th }}$ century BC and $7^{\text {th }}$ century CE.
\end{abstract}

Keywords: sedimentary hiatuses, moorsh horizons, climate change, palaeobotanical analysis, Atlantic period.

\section{INTRODUCTION}

Horizons of strongly decomposed peat (HSDP), known as moorsh horizons in the Polish soil classification system and muck horizons in the terminology of North American agriculture (Okruszko and Ilnicki, 2003), are a valuable indicator of paleohydrological changes in mires. They not only indicate hiatuses in peat accretion, but also indicate a long-term negative balance of peatland productivity in conditions in which there is a significant drop in the groundwater level. 
On the territory of Poland, HSDP are usually observed in acrotelm layers in modern peatlands. In the case of minerotrophic mires, this usually applies to fens and wet meadows populated by phytocenoses that are dominated by sedges, and possibly to swamps overgrown with forest communities including common alder (e.g. Tomaszewska and Kołodziejczyk, 2010; Forysiak, 2012; Kołodziejczyk, 2013; Forysiak et al., 2014). Similar processes can also be observed in ombrotrophic mires as exemplified by the Rąbien bog, which is being overgrown by the Vaccinio uliginosi-Pinetum forest community (Kloss and Żurek, 2005; Kloss, 2007). In most cases, contemporary peat decay processes can be linked to human activities, and in particular to the agricultural use of meadows and pastures (see Kołodziejczyk, 2013). Fossil HSDP are more valuable for the reconstruction of paleohydrological changes that were conditioned by climate. Such changes have been recorded, inter alia, in Alneti, Saliceti, Eriophoro-Sphagneti and Bryaleti peat layers from the mires of eastern Poland and were used to construct the chronology of dry and wet phases in the Late Glacial and Holocene (Żurek and Pazdur, 1999; Żurek et al., 2002). Despite the clearly indicated potential, there are difficulties in using HSDP results in paleohydrological studies. The problem is the asynchronicity of the development of hiatuses at nearby sites. For example, in peat deposits in central Poland, hiatuses are frequently found that cover the Atlantic and early Subboreal periods (Forysiak, 2012). In the Wilczków mire located within the Warsaw-Berlin ice-margin valley and in the Kopanicha mire in the Rawka River valley, rapid peat accretion was observed during the same period (Forysiak, 2012; Forysiak et al., 2014). Another issue is the difficulty associated with the precise determination of the age of paleohydrological changes, which is manifested in radiocarbon dates that are not in line with those derived from pollen analysis. Problems of this kind arose e.g. during the interpretation of the Machnacz III core on the Białystok Plateau (Żurek and Pazdur, 1999) as well as of the Mianów core in the Ner River valley (Forysiak, 2012). Both categories of problems were encountered during the interpretation of fossil HSDP discovered in peat deposit sequences in valley mires in the upper basin of the Oder River (see Nita and Wójcicki, 2005; Wójcic$\mathrm{ki}, 2013)$.

The article presents the results of research on the chronology and determinants of HSDP development in peat sequences in the Racibórz Basin and analyses the relationships between plant succession and the productivity of the mires examined. In the context of the mechanism of HSDP formation and the conditions that determine the resumption of peat accumulation, the limitations of absolute dating of dry and wet phases with respect to mires are discussed.

\section{MATERIALS AND METHODS}

The study sites discussed are located in the Racibórz Basin (sensu Kondracki, 1998). According to data of System Informacji Przestrzennej o Mokradłach Polski (2006), 30 mires have been identified there, covering a total area of $c a .1,340$ ha (i.e. approximately $1.1 \%$ of the area of the mesoregion). It should be noted that this list does not include the small (less than 10 ha) but quite numerous valley mires, which have mostly developed in oxbow lakes. It is precisely these mires that were the main focus of the studies conducted. In the course of many years, nearly thirty peat sequences from the Oder, Ruda, Kłodnica and Osobłoga River valleys were analysed (Wójcicki, 2000; Nita and Wójcicki, 2005; Wójcicki et al., 2010; Wójcicki, 2013). Pollen analysis was conducted for seven Late Glacial/Early Holocene mires; mid-Holocene hiatuses were identified in as many as five of those (including at the Chechło site in the Kłodnica River basin). The accumulation of deposits correlated with the Atlantic period using pollen dating was only confirmed for the Ujazd/Zandrzyny (between Łany Małe and Sławięcice in the Kłodnica River valley) and Żywocice (Osobłoga River valley) cores. Fossil HSDP were found at four sites, which are the subject of this article (Fig. 1). These include the small (0.9 ha) and shallow (up to $1 \mathrm{~m}$ ) Ruda Kozielska fen developed in a Ruda River oxbow lake (Fig. 1A); the shallow and fairly extensive (about 11 ha) fen in Łany Małe that developed at the foot of the Kłodnica valley-sides (Fig. 1B); and the small (1.6 ha and 2.0 ha respectively), but relatively deep (up to 2.7 and $4.0 \mathrm{~m}$ ) fens developed in the abandoned channels of the Kłodnica River, referred to as Sławięcice 1 (Fig. 1C) and Sławięcice 2 (Fig. 1D). A broader genetic and lithological description of the aforementioned mires is included in earlier publications (Wójcicki, 2000; 2013; Wójcicki and Kloss, 2008).

During the field studies, HSDP were identified as intensively dark layers of amorphous peat (see Żurek et al., 2002). Drilling was undertaken at the individual sites, which confirmed the continuity of decomposed peat layers in the horizontal cross-section of the mires analysed. Sediment cores with intact structure were collected using a Russian D-Sampler. At the Sławięcice 2 site, the analysis included a sequence of deposits collected at a distance of about 10 metres from the thalweg zone in the paleochannel because the record of peat decay was the most visible in that zone (see Wójcicki, 2013). It should be noted at this point that the black colour of peat layers can also be related to a high concentration of sulphur compounds (total sulphur $>5 \%$ ). Such a case was identified at the Głogówek site in the Osobłoga River valley. Radiocarbon dating showed no break in the continuity of deposit accumulation at that depth (Wójcicki, 2013). 

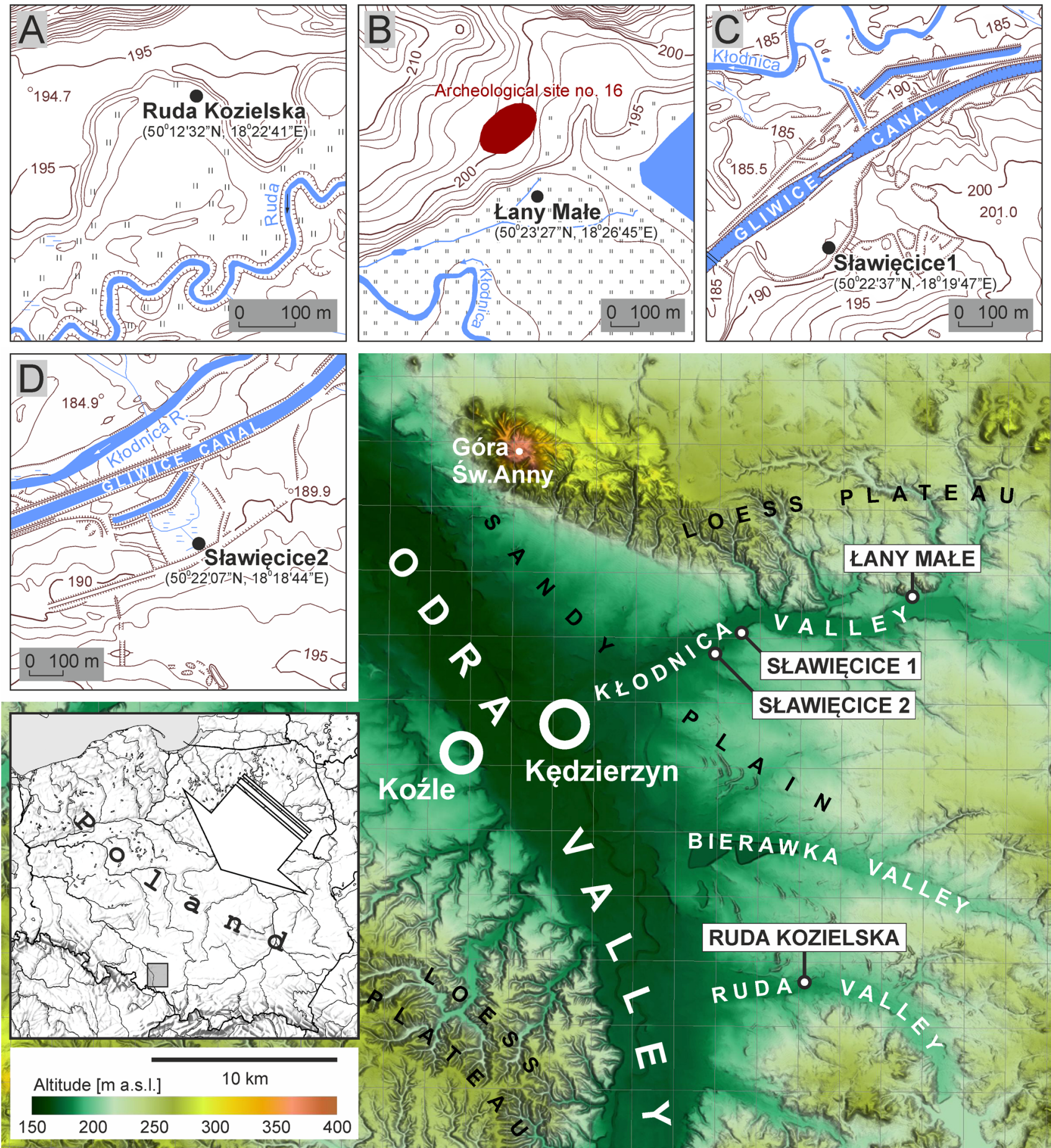

Fig. 1. Location of the Ruda Kozielska (A), Łany Małe (B) Sławięcice 1 (C) and Sławięcice 2 (D) study sites.

Laboratory methods were selected in order to verify the presence of HSDP in peat sequences (pollen analysis and radiocarbon dating) and to reconstruct the environmental conditions that accompanied their formation. Firstly, on the basis of lithologic features, the cores examined were divided into homogeneous sections, usually few centimetres thick. The origin of the deposits and the composition of the subfossil peat-forming communities were established on the basis of macrofossil analysis. The analysis covered both vegetative remains and carpological findings. Using the microscopic grid method, the percentage shares of amorphous organic matter and carbonised phytoclasts in peat were determined. Pollen analysis was used to describe vegetation changes on a region- 
al scale and to assess the human impact on the environment in various phases of the Holocene. The presence of charcoal and carbonaceous dust that provided evidence of fires in the peatland area was observed during the analysis. Samples for pollen analysis were prepared using $10 \%$ $\mathrm{KOH}, 10 \% \mathrm{HCl}, 40 \% \mathrm{HF}$ and Erdtman's acetolysis method (Faegri and Iversen, 1978). The calculation was based on the sum of tree and shrub pollen (AP) and of terrestrial herb and dwarf shrub pollen (NAP). Radiocarbon dating was used to determine the absolute age of deposits. Peat and wood samples as well as separate seeds were analysed by conventional beta counting or AMS methods at the Kyiv, Poznań and Gliwice Radiocarbon Laboratories (Table 1). The radiocarbon dates were calibrated using the OxCal 4.2.4 radiocarbon calibration programme (Bronk Ramsey, 2009) and IntCal13 atmospheric curve (Reimer et al., 2013).

\section{RESULTS}

\section{Ruda Kozielska Site}

In the Ruda Kozielska core, the greatest degree of decomposition is exhibited by peat at a depth of $60-51 \mathrm{~cm}$. The deposits in question are black (10YR2/1 according to the Munsell Soil Color Charts) due to the presence of carbonised plant tissues and humic substances. A sedimentary discontinuity at a depth of $60-50 \mathrm{~cm}$ was reflected in the pollen analysis results. Abrupt changes in the percentage share of pollens (including that of Alnus and Poaceae pollen) can be observed in this zone (Fig. 2). For a deposit sample from a depth of 55-51 cm, which included alder root wood penetrating layers of degraded peat, the date 4690-4350 cal BC was obtained. Pollen spectra from this depth indicate the development of alder forests in the river valley and of mixed deciduous forests on inter-valley areas. Macrofossil composition documents the development of a forest swamp dominated by common alder (Fig. 3). Above the HSDP roof, silty alluvia are present which contain charcoals. In the overbank layer, an increase in the share of sedge epidermis was noted together with the encroachment of birch - probably a reflection of regeneration processes after a fire on the overdrying mire. The resumption of peat accumulation was dated to the turn of the Common Era (Table 1, Poz23205). This occurred during late Holocene changes in the local forest communities, which were related, inter alia, to an increase in the share of oak, beech and hornbeam and the decline in importance of lime and hazel. Macrofossil analysis demonstrates that trees began to recede from the peatland. In their place, sedge communities developed on a large scale, which also included mosses, and habitat hydration increased, which is evidenced by the emergence of bioindicators of an aquatic environment (Chironomidae and Cladocera remains).

\section{Lany Male Site}

The HSDP roof in the Łany Małe core occurs at a depth of $58 \mathrm{~cm}$. The use of the radiocarbon method confirmed the discontinuity in deposit accumulation. The dating of a sample from a depth of $63-58 \mathrm{~cm}$ yielded the result of 3510-2930 cal BC while the overlying peat layer from a depth of 58-53 cm was dated to $1050-790 \mathrm{cal} \mathrm{BC}$. The presence of a stratigraphic gap is underscored in the pollen diagram by the occurrence of very large quantities of carbonaceous dust and just a few unidentifiable pollen grains at a depth of about $58 \mathrm{~cm}$ (Fig. 4). Pollen spectra from a depth of 75-60 cm still show the broad development of pine communities with a small share of oak (Quercus) and hazel (Corylus) characteristic of the early Boreal, and the beginning of the development of alder

Table 1. Dated material and results of radiocarbon dating of sediments from the sites Łany Małe (ŁM), Ruda Kozielska (RK), Sławięcice 1 (Sw1) and Sławięcice 2 (Sw2).

\begin{tabular}{|c|c|c|c|c|c|}
\hline Core & $\begin{array}{l}\text { Depth } \\
\text { (cm) }\end{array}$ & Dated material & Lab. code & $\begin{array}{l}{ }^{14} \mathrm{C} \text { age } \\
\text { (BP) }\end{array}$ & $\begin{array}{c}\text { Cal. age (BC/AD)* } \\
\text { Conf. level } 95 \%\end{array}$ \\
\hline \multirow{3}{*}{ RK } & $36-38$ & seeds; i.a. Sambucus nigra & Poz-23205 & $1975 \pm 30$ & $50 \mathrm{BC}-\mathrm{AD} 80$ \\
\hline & $51-55$ & alder peat & Ki-7161 & $5660 \pm 80$ & $4690 \mathrm{BC}-4350 \mathrm{BC}$ \\
\hline & $85-89$ & alder peat & Gd-10225 & $6010 \pm 120$ & $5230 \mathrm{BC}-4610 \mathrm{BC}$ \\
\hline \multirow{4}{*}{$Ł M$} & $21-26$ & mainly roots of Carex and Alnus periderm & Ki-7583 & $1720 \pm 80$ & AD $120-A D 540$ \\
\hline & $53-58$ & alder peat & Ki-7569 & $2720 \pm 70$ & $1050 \mathrm{BC}-790 \mathrm{BC}$ \\
\hline & $58-63$ & alder peat & Ki-7570 & $4530 \pm 80$ & $3510 B C-2930 B C$ \\
\hline & $86-91$ & alder peat & Ki-7571 & $6240 \pm 70$ & $5360 \mathrm{BC}-5010 \mathrm{BC}$ \\
\hline \multirow{5}{*}{ Sw1 } & $33-38$ & alder peat & Ki-7566 & $1305 \pm 70$ & AD $610-A D 890$ \\
\hline & $77-79$ & Rubus idaeus and Sambucus nigra seeds & Poz-23206 & $2130 \pm 30$ & $350 \mathrm{BC}-50 \mathrm{BC}$ \\
\hline & $79-84$ & alder peat & Ki-7567 & $3755 \pm 70$ & $2460 \mathrm{BC}-1960 \mathrm{BC}$ \\
\hline & $150-155$ & Pinus wood & Ki-7568 & $8050 \pm 80$ & $7290 \mathrm{BC}-6690 \mathrm{BC}$ \\
\hline & 263-267 & brown moss peat & Ki-7157 & $9400 \pm 90$ & $9130 \mathrm{BC}-8350 \mathrm{BC}$ \\
\hline \multirow{4}{*}{ Sw2 } & $28-32$ & sphagnum moss-sedge peat & Ki-11229 & $200 \pm 60$ & AD 1520 - present \\
\hline & $70-72$ & Filipendula ulmaria, Sambucus nigra and Rubus idaeus seeds & Poz-23211 & $1395 \pm 30$ & AD $600-A D 680$ \\
\hline & $72-84$ & alder peat & Ki-13092 & $4290 \pm 60$ & $3100 B C-2690 B C$ \\
\hline & 198-204 & mainly roots and epidermis of reed & Ki-11230 & $7480 \pm 60$ & $6450 \mathrm{BC}-6230 \mathrm{BC}$ \\
\hline
\end{tabular}

*OxCal 4.2.4 (Bronk Ramsey, 2009); IntCal13 atmospheric curve (Reimer et al., 2013) 


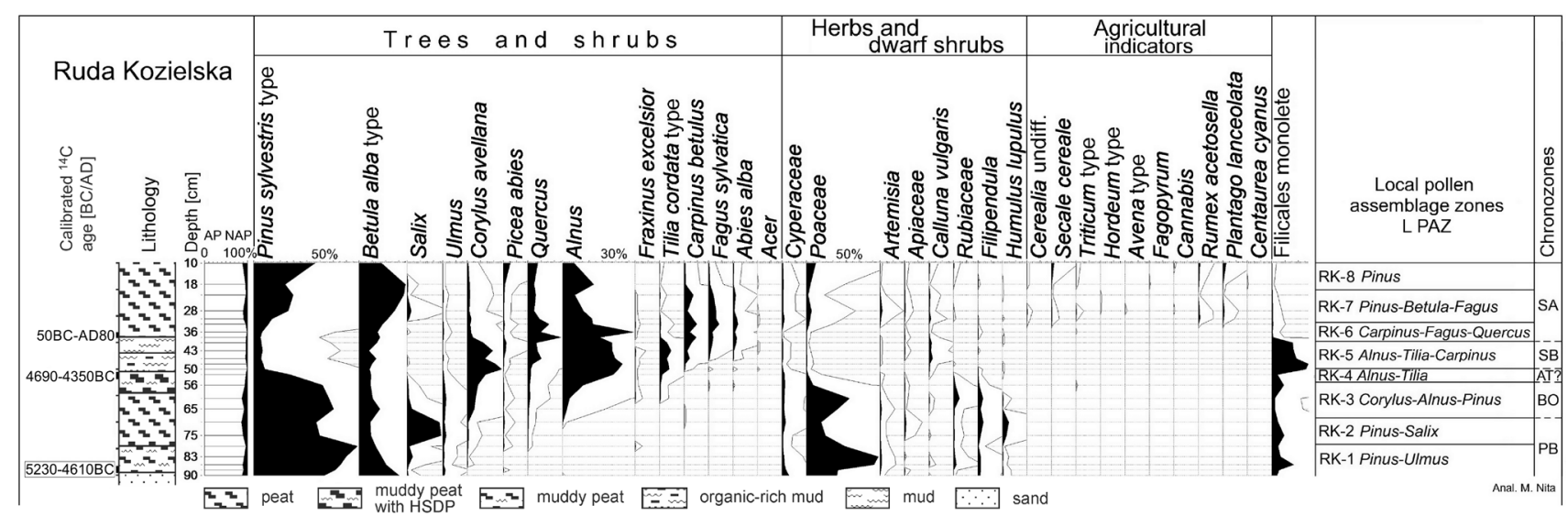

Fig. 2. Simplified pollen diagram from the Ruda Kozielska core, Ruda River valley.

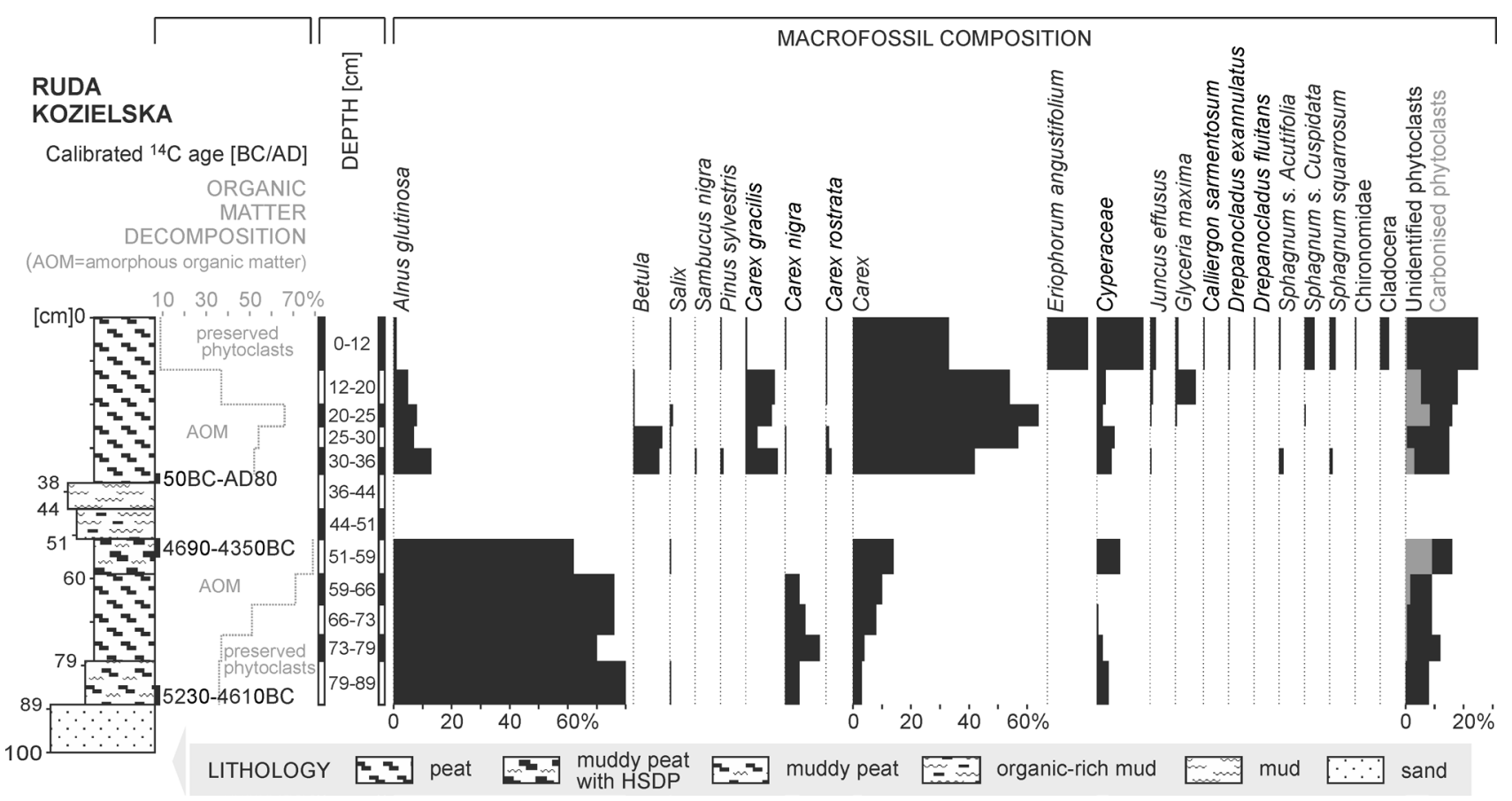

Fig. 3. Macrofossil diagram from the Ruda Kozielska core, Ruda River valley.

communities including elm (Ulmus) and ash (Fraxinus). On the other hand, deposits from a depth of $55-45 \mathrm{~cm}$ can be associated with the Subboreal period, e.g. on the basis of the presence of Carpinus, Fagus and Abies pollen. In peat below the depth of $58 \mathrm{~cm}$, fragments of common alder wood and periderm clearly dominate (Fig. 5). Numerous wood remains are carbonised. The composition of the peat, which indicates the development of the Ribeso nigri-Alnetum forest community, does not change substantially in the sample located above the HSDP roof. Initially, only the increase in the share of periderm at the expense of wood can be noticed there. Trees only recede in the youngest mire development stage when sedge communities including Carex appropinquata spread (Wójcicki and Kloss, 2008).

\section{Sławięcice 1 Site}

A layer of dark (5Y2.5/1), highly decomposed peat is present in the Sławięcice 1 core at a depth of 108-79 cm. The presence of a hiatus was confirmed by palynological means. The analysis of a sample from a depth of $80 \mathrm{~cm}$ revealed the presence of a non-pollen layer containing large quantities of carbonaceous dust (Fig. 6). The pollen spectrum of deposits from a depth of $85 \mathrm{~cm}$ indicates a significant share of pine in the forest communities, which is characteristic of the early Holocene, and insignificant shares of alder, hazel and oak. On the other hand, the 


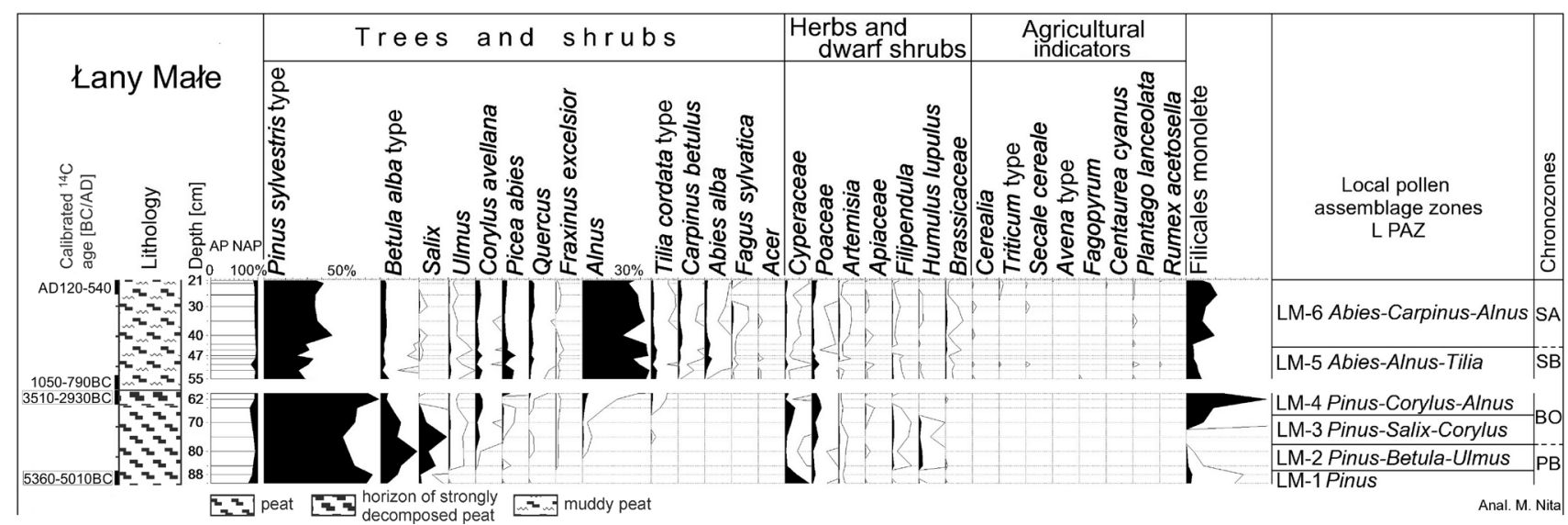

Fig. 4. Simplified pollen diagram from the Łany Małe core, Kłodnica River valley.

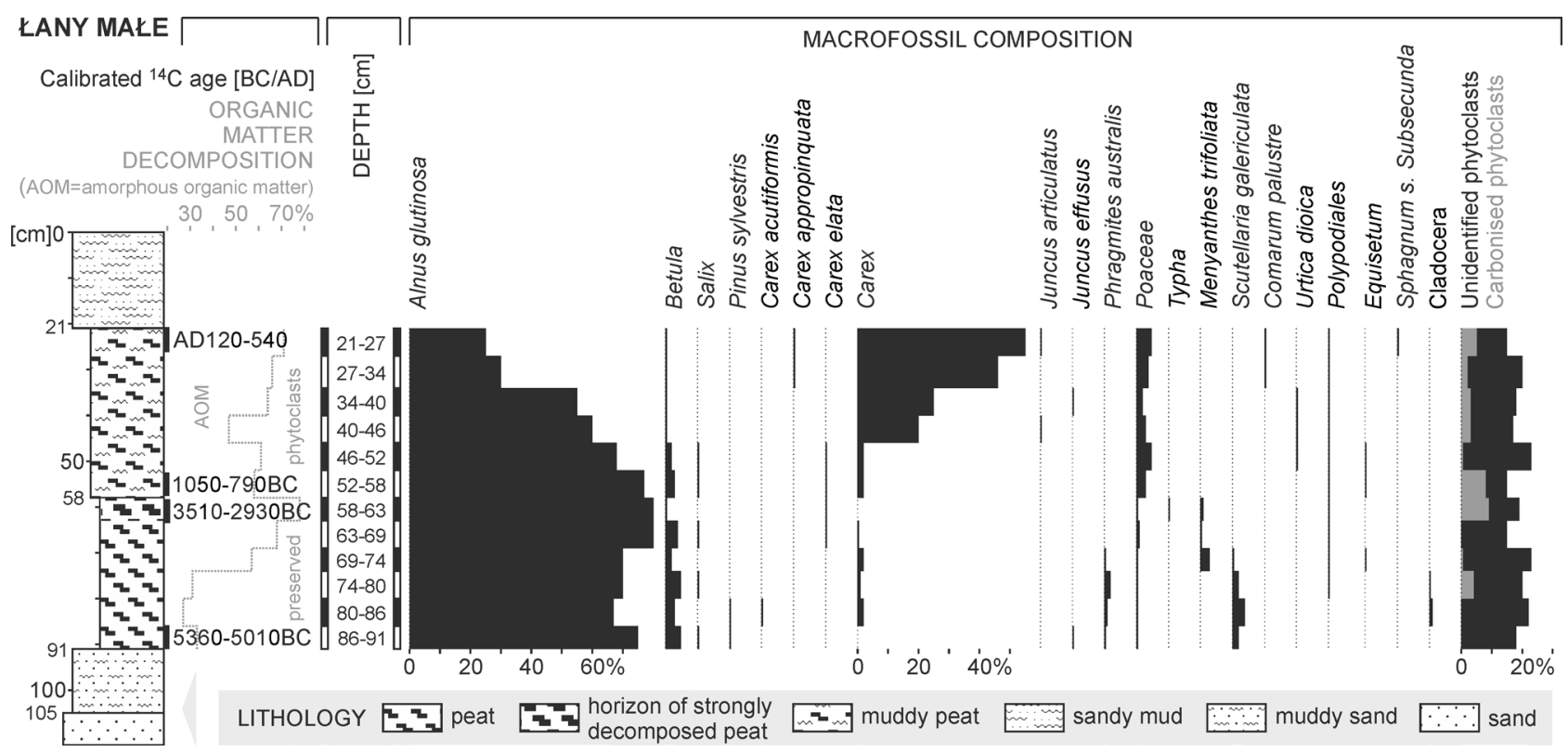

Fig. 5. Macrofossil diagram from the Łany Małe core, Kłodnica River valley.

presence of Carpinus, Fagus and Abies pollen in samples collected at a depth of $75-65 \mathrm{~cm}$ suggests a correlation with the late Holocene. In the light of macrofossil analysis (Fig. 7), the upper HSDP layer is dominated by Alnus glutinosa wood which, given the presence of Rubus idaeus drupelets above, appears to provide evidence for the development of a Ribeso nigri-Alnetum swamp forest. Radiocarbon dating of the $84-79 \mathrm{~cm}$ layer yielded a result of $2460-1960 \mathrm{cal}$ BC. This is overlain by slightly lighter (7.5YR2.5/1) peat still containing a high wood content, which is characterised by an increase in the share of alder periderm and sedge rootlets. Radiocarbon dating of a sample from the 79-77 cm layer yielded a result of 35050 cal BC. With time, the trees receded from the mire and were succeeded by sedge communities with species $(C$. elata and C. gracilis) characteristic of phytocenoses from the Magnocaricion alliance.

\section{Slawięcice 2 Site}

The highest share of amorphous matter (63\%), accompanied by a high share of carbonised phytoclasts (7\%), was recorded in a level of dark (5Y 2.5/1) alder peat at a depth of 84-72 cm. Macrofossil analysis demonstrated the domination of common alder wood in this level, accompanied by Carex and Equisetum rootlets and epidermis. Radiocarbon dating of this layer produced a date of 3100-2690 cal BC. Like the previous site, the Sławięcice 2 core also includes a non-pollen layer at a depth of about $80 \mathrm{~cm}$ that includes a large amount of carbonaceous dust. Pollen spectra of the deposits underlying this layer can be correlated with the older part of the 


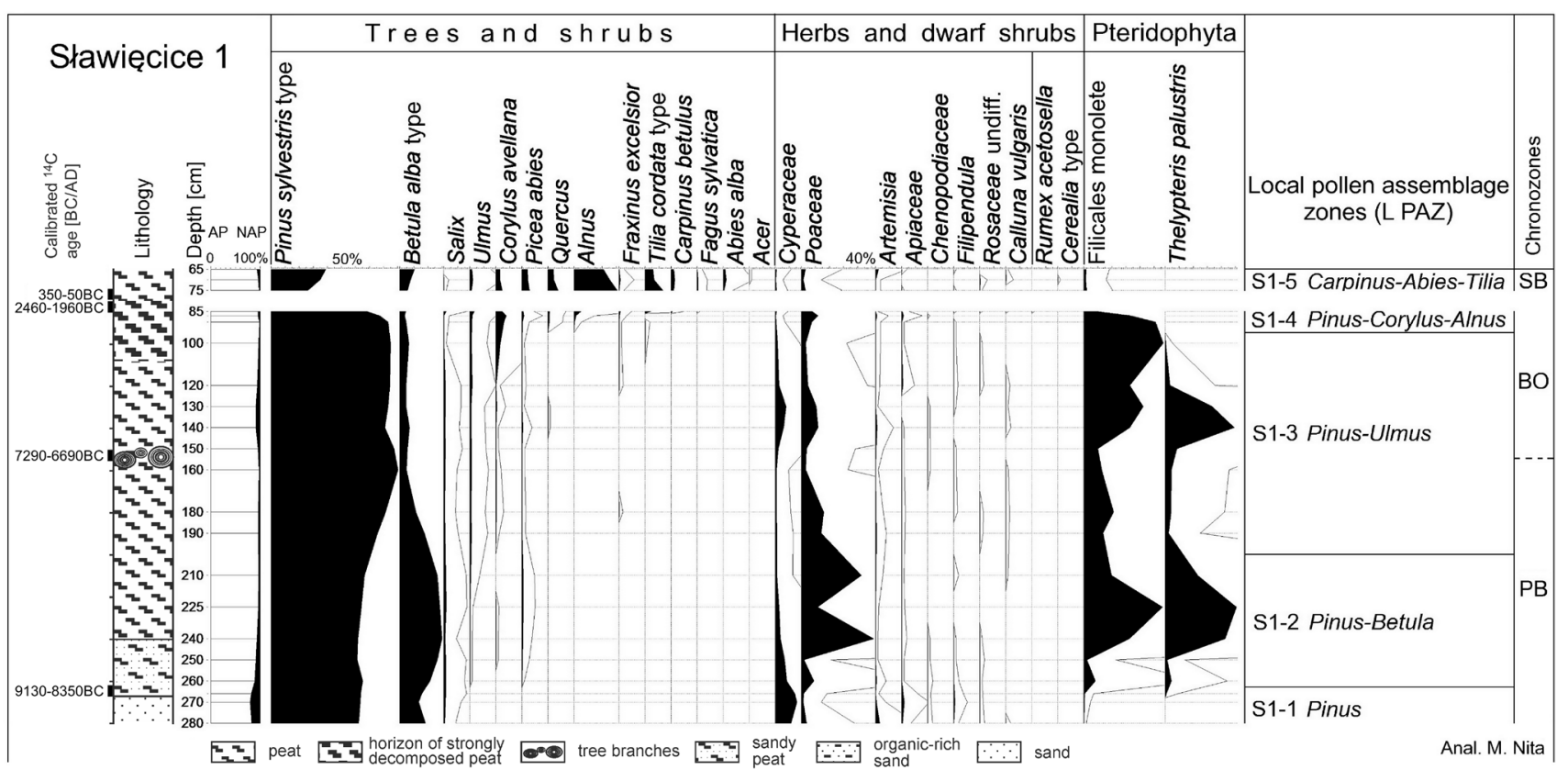

Fig. 6. Simplified pollen diagram from the Sławięcice 1 core, Kłodnica River valley.

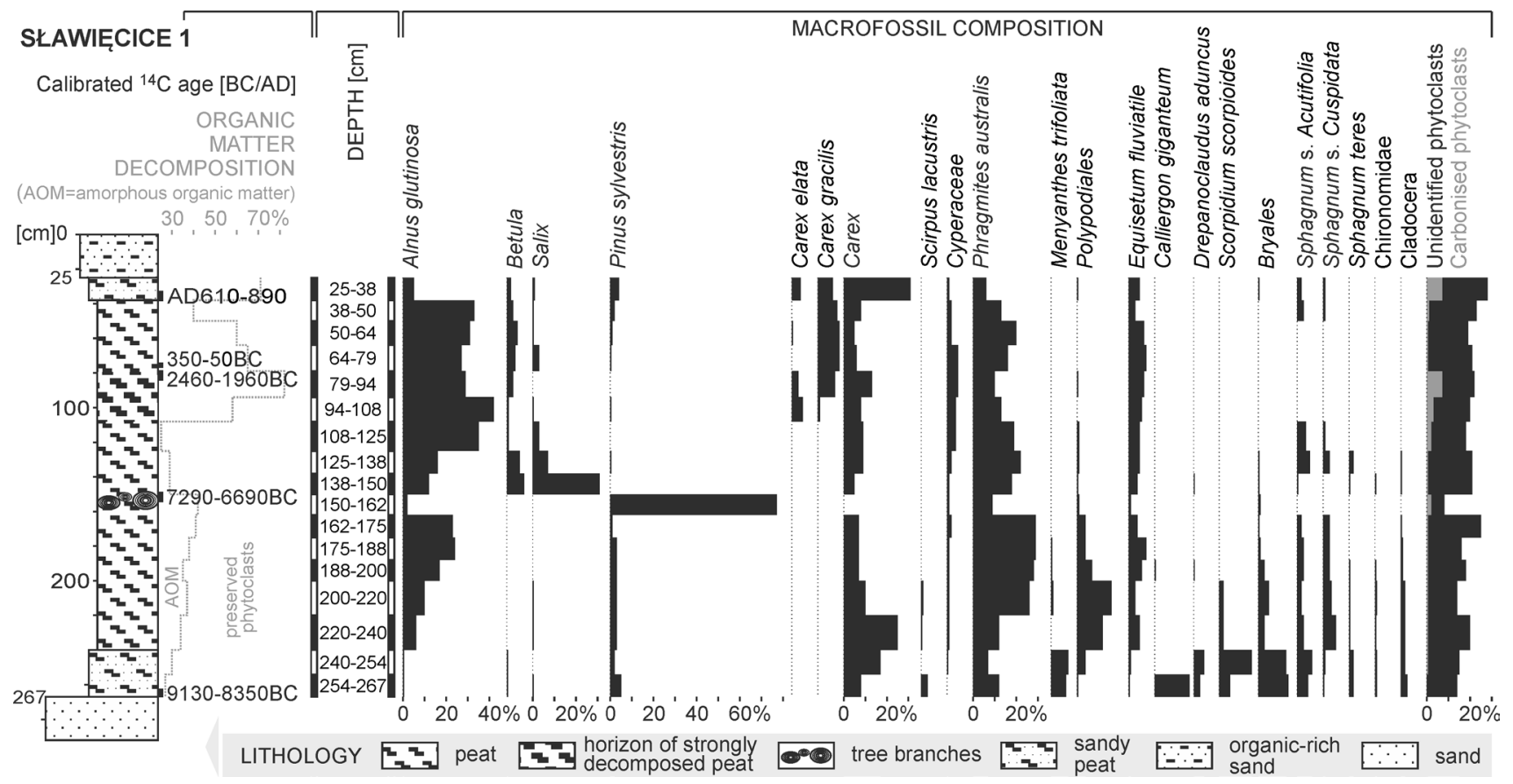

Fig. 7. Macrofossil diagram from the Sławięcice 1 core, Kłodnica River valley.

Boreal period while the overlying deposits indicate the late Holocene (Fig. 8). Carpological material (Filipendula ulmaria, Sambucus nigra and Rubus idaeus seeds), which was dated to cal AD 600-680, was obtained from the overlying, less degraded peat at a depth of 70-72 cm. In this sample, the shares of amorphous matter (47\%) and carbonised phytoclasts (5\%) decreased (Fig. 9). The share of sedge remains temporarily increased at this depth in the peat sequence but the macrofossil composition indicates that a forest community dominated by common alder was still present on the mire. Only from a depth of $32 \mathrm{~cm}$ upwards is the complete disappearance of trees from the mire noticeable coupled with the development of sedge-moss communities with a significant share of 


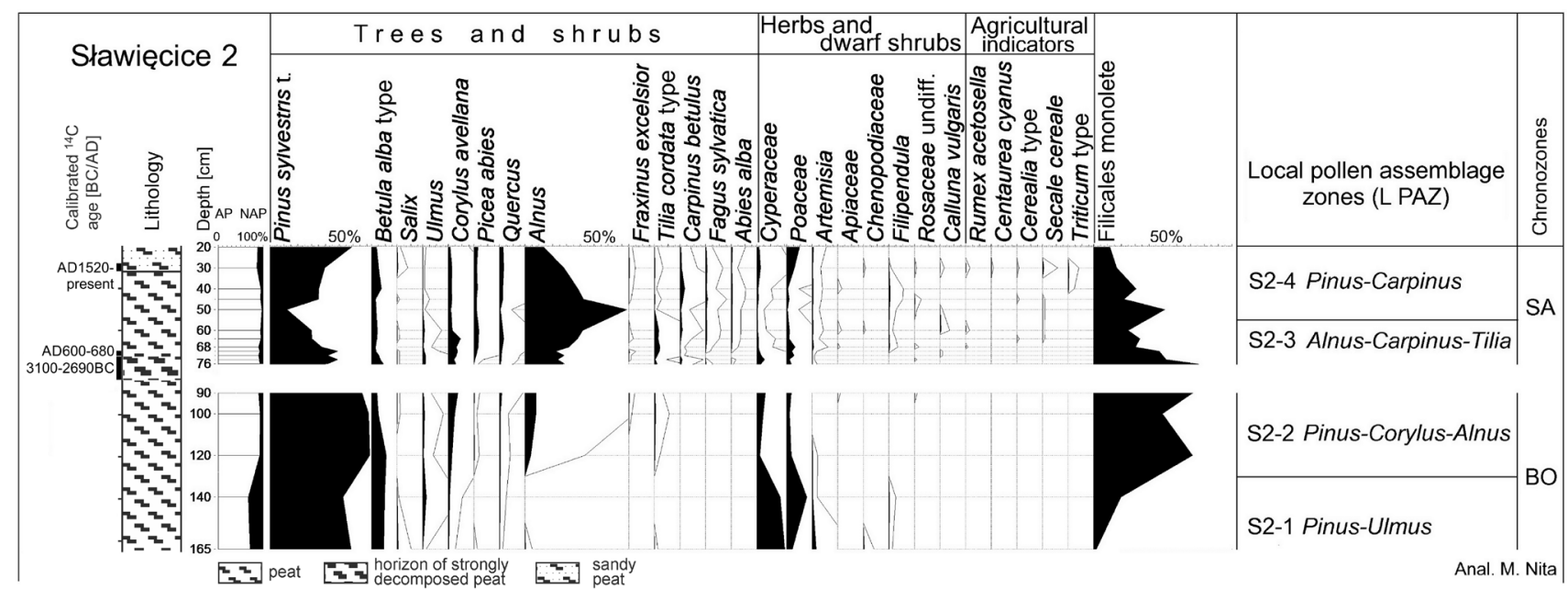

Fig. 8. Simplified pollen diagram from the Sławięcice 2 core, Kłodnica River valley.

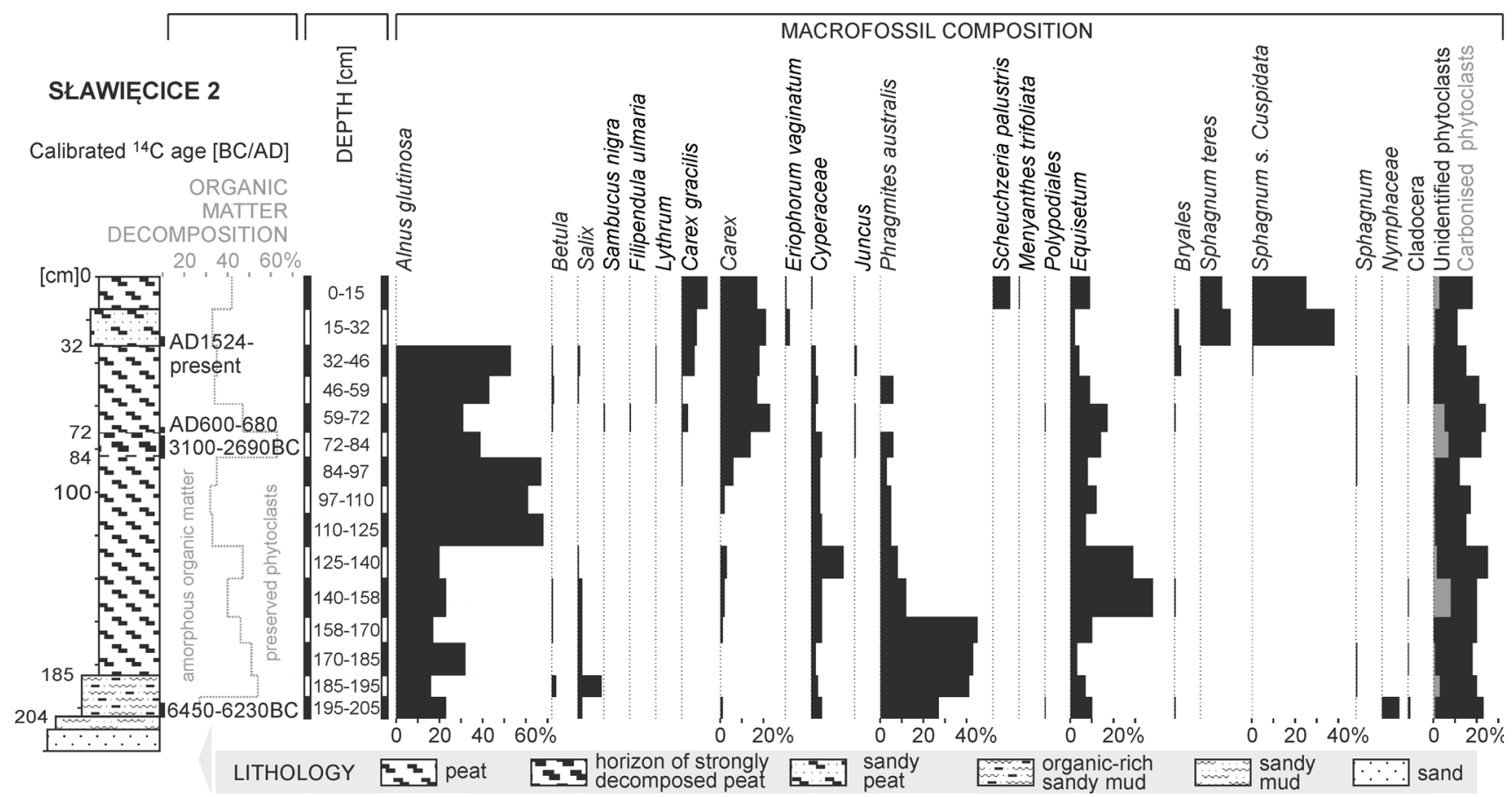

Fig. 9. Macrofossil diagram from the Sławięcice 2 core, Kłodnica River valley.

Sphagnum mosses. This phase was preceded by the appearance of Cladocera remains as bioindicators of an aquatic environment.

\section{DISCUSSION}

The endo/exogenous conditions accompanying the selective development of HSDP in the mires of the Racibórz Basin

The mid-Holocene peat decay was not recorded in all peat sequences in the Racibórz Basin. In the light of radi- ocarbon dating, it is evident that during the Atlantic Period a relatively high accumulation rate of $c a .1 \mathrm{~mm} /$ year was exhibited by the Ujazd/Zandrzyny site where, given higher habitat humidity, Phragmitetea class communities developed (Wójcicki, 2013). These were dominated by common reed and sedges. On the Żywocice site, no HSDP formed in the middle Holocene despite the development of a forest dominated by alder at that time (Wójcicki, 2000). These examples show that HSDP could only form where a proper combination of climate and local factors existed. First of all, the mires had to be at an advanced stage of development so that the plant commu- 
nities overgrowing them could respond to signals of hydrological change.

Paleobotanical analyses demonstrate that HSDP could develop in shallow mires formed both as a result of the paludification of distal floodplains (as in the case of the Lany Małe site) and the terrestrialisation of relatively deep oxbow lakes (as at the Sławięcice 1 and Sławięcice 2 sites). A common feature of all the study sites is that peat decay took place at the stage when a forest swamp community dominated by common alder developed. These observations contribute to the broader debate concerning the productivity of alder swamps (see Tobolski, 2000). While the peat-forming abilities of alder forest are unquestionable (Marek, 1965), in the forest phase of mire development a decrease in accumulation rate or even the decay of previously accumulated deposits is usually observed (e.g. Grosse-Brauckmann, 1986; Harmata, 1995). The reasons for this state of affairs can be complex. Alder swamps receive direct precipitation as well as groundwater inflow, with a small role of inundation waters (Matuszkiewicz, 2005). The consequence of such water relations may be the periodic advantage of aerobic processes in the acrotelm layer, with peat aeration in forest habitats potentially increased due to the penetration range of tree root systems (Tobolski, 2003). Either way, the key issue for the development of HSDP is the fact that the spread of alder forests in river valleys and the hydrological changes observed in North-Western and Central Europe (within the zone affected by the North Atlantic) were synchronous events. The results of paleohydrological studies provide ever more evidence that in the more recent part of the Atlantic period, water levels lowered in both lakes (e.g. Ralska-Jasiewiczowa and Starkel, 1988; Magny et al., 2003) and mires (e.g. Rybníček and Rybníčkova, 1987; Żurek et al., 2002; Caspers and Grosse-Braukmann, 2003). In central Poland, hiatuses during the Atlantic and Subboreal periods have been identified, inter alia, in the Bartochów, Ner-Zawada, Milanów, Korzeń, Bęczkowice, Ługi and Józefka cores (Forysiak, 2012). In southern Poland, hiatuses from the Atlantic period have also been found, including, inter alia, at the following sites: Nowa Huta in the Vistula River valley (Kalicki and Zernickaya, 1995), and Słopiec (Szczepanek, 1982) and Napęków (LudwikowskaKędzia, 2000) in the Belnianka River valley. In the Roztoka A and B, Jasło and Tarnowiec cores (the JasłoSanok Depression), the accumulation of peat was interrupted or reduced (Harmata 1987; 1995).

After a period of peat decay, a return to peat accumulation was observed during the late Holocene in all the cores examined. Macrofossil analysis shows that changes in the peatland balance of productivity had already started at the time when swamp forests dominated by alder prevailed. The peat layers directly overlying the HSDP roof in the Lany Małe and Sławięcice 1 cores contain even more tree remains. The increase in the share of periderm could have been the result of the accumulation of above- ground remains on a long-term stable mire surface. Over time, the composition of the remains preserved in the peat, which resumed its accumulation, changed, reflecting the adaptation of plant communities to more humid habitats. In the sequences of deposits analysed, a shift was observed towards non-forest, sedge-moss communities belonging to the Magnocaricion alliance or the Scheuchzerio-Caricetea nigrae class. The increase in habitat hydration was confirmed by the appearance of bioindicators of an aquatic environment (Cladocera and Chironomidae remains). The directions of succession described above testify to the slow transformation of habitats under the influence of elevated water levels in mires. These changes cannot be explained as the effect of endogenous factors. They must have been caused by climate conditions or human impact. Radiocarbon dating indicates that they can be correlated with the appearance of settlements of prehistoric cultures in the study area: the Lusatian culture between the $9^{\text {th }}$ and $3^{\text {rd }}($ ?) centuries BC and the Slavic settlement from the $7^{\text {th }} / 8^{\text {th }}$ century onwards (Abłamowicz and Śnieszko, 2001; Foltyn et al., 2004). At that time, significant deforestation had occurred, which must have affected water relations in the valley bottoms. However, pollen analysis does not provide conclusive evidence in this respect. Indicators of human activity appear in the Lany Małe core alongside the resumption of peat accumulation. At the Ruda Kozielska and Sławięcice 2 sites, pollen of grain, forage and weed species occurs slightly later than in the Łany Małe core. In general, it appears that the transition from the dry phase to the wet phase registered in Polish peat sequences was not a synchronous one (Fig. 10). According to Żurek et al. (2002), the increase in humidity occurred on the boundary between the Atlantic and Subboreal periods. However, the studies conducted in the Belnianka River valley indicate that the resumption of peat accumulation in the Słopiec II core started in the mid-Subboreal period (Szczepanek, 1982). According to palynological determinations, in the Napęków 8 core the accumulation of peat began between ca. 3800 and 2800 cal BC, but only gathered pace in the middle Subboreal period (Ludwikowska-Kędzia, 2000). The accumulation of peat in the Nowa Huta core in the Vistula River valley probably resumed during the Subboreal period (Kalicki and Zernickaya, 1995). On the other hand, the resumption of peat accumulation at most sites in central Poland, (including Bartochów, NerZawada, Bęczkowice, Wilczków, Ługi and Józefka), is associated with the Subatlantic period. This only occurred in the Subboreal period in the Milanów and Korzeń cores (Forysiak, 2012).

\section{A model of HSDP formation and the problem of da- ting dry and wet phases in mires}

The mechanisms that determine mire productivity sometimes make it difficult to date wet and dry phases in mires since ${ }^{14} \mathrm{C}$ dating results are inconsistent with pollen data. 


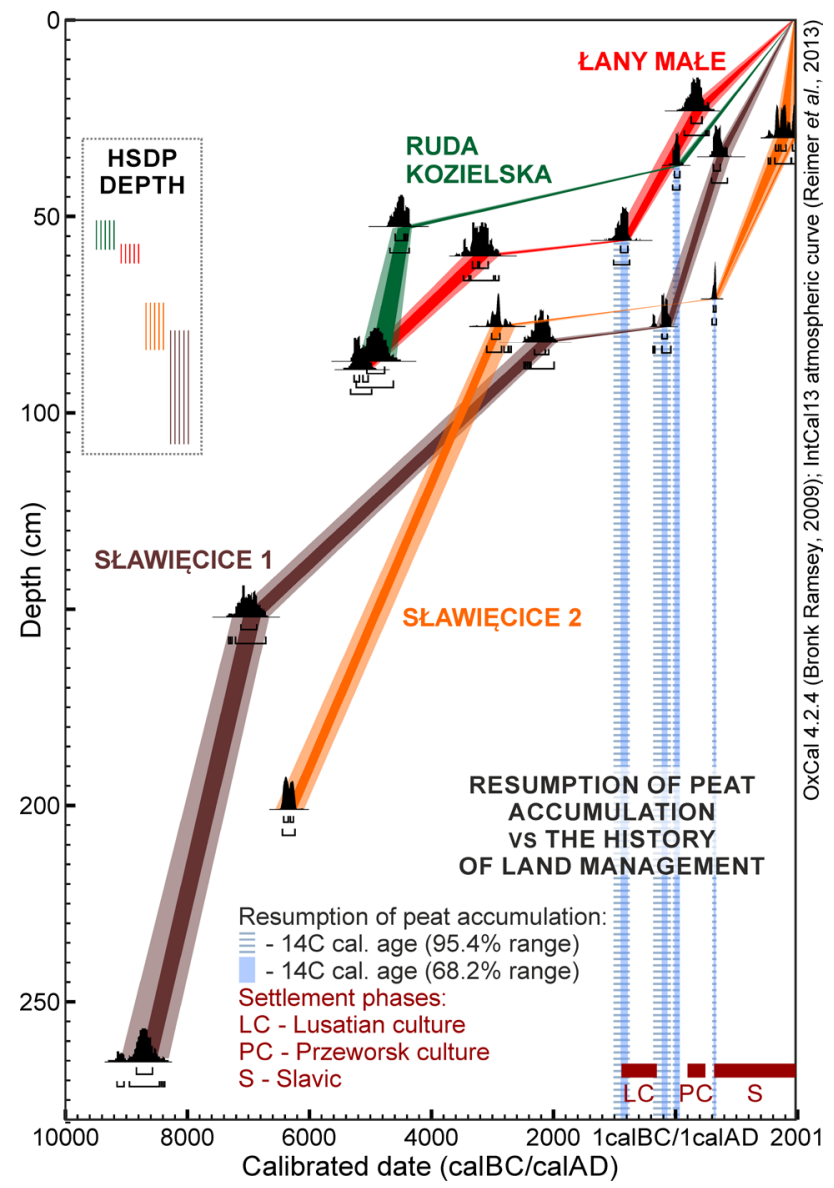

Fig. 10. Age-depth models of the studied cores.
Particular methodological problems are related to the dating of dry phases during which HSDP form. Pollen spectra from a depth of 75-60 cm in the Lany Małe core enable the correlation of sediments with the Boreal period, which is inconsistent with the date of 3510-2930 cal $\mathrm{BC}$ (at a depth of $63-58 \mathrm{~cm}$ ). A similar situation occurs at the Sławięcice 1 site where the date of 2460-1960 cal BC was obtained at a depth of 84-79 $\mathrm{cm}$. While at a depth of $80 \mathrm{~cm}$ a non-pollen layer was present, just below it (at a depth of $85 \mathrm{~cm}$ ) pollen spectra indicated the Boreal period. In the Sławięcice 2 core, pollen spectra from a depth of 100-90 cm suggest also an early Holocene age, which is inconsistent with the date of 3100-2690 cal BC (at a depth of $72-84 \mathrm{~cm}$ ). The above results demonstrate that HSDP contain organic matter of different ages - both from the period in which the decay process took place (mainly intrusive alder wood) and older, usually strongly decayed matter from the degraded peat layer. The significant age difference between pollen analysis results and the ${ }^{14} \mathrm{C}$ dates obtained indicates that the postsedimentological decay processes involved ever deeper levels of previously accumulated peat. Given the negative balance of peat productivity, the mire surface probably became lower (Fig. 11).

The situation at the Ruda Kozielska site could have been slightly different. There, pollen analysis demonstrates that deposit continuity was probably disturbed at a depth of 60-50 cm. The underlying deposits (at a depth of $70-60 \mathrm{~cm}$ ) may be associated with the Boreal period, and the overlying ones (at a depth of 50-40 cm) - with the Subboreal period. Deposits from the top HSDP layer, at a depth of 55-51 cm, were dated to 4690-4350 cal BC, i.e. to the Atlantic period. In general, pollen spectra from that depth are not inconsistent with that date. On this basis, it

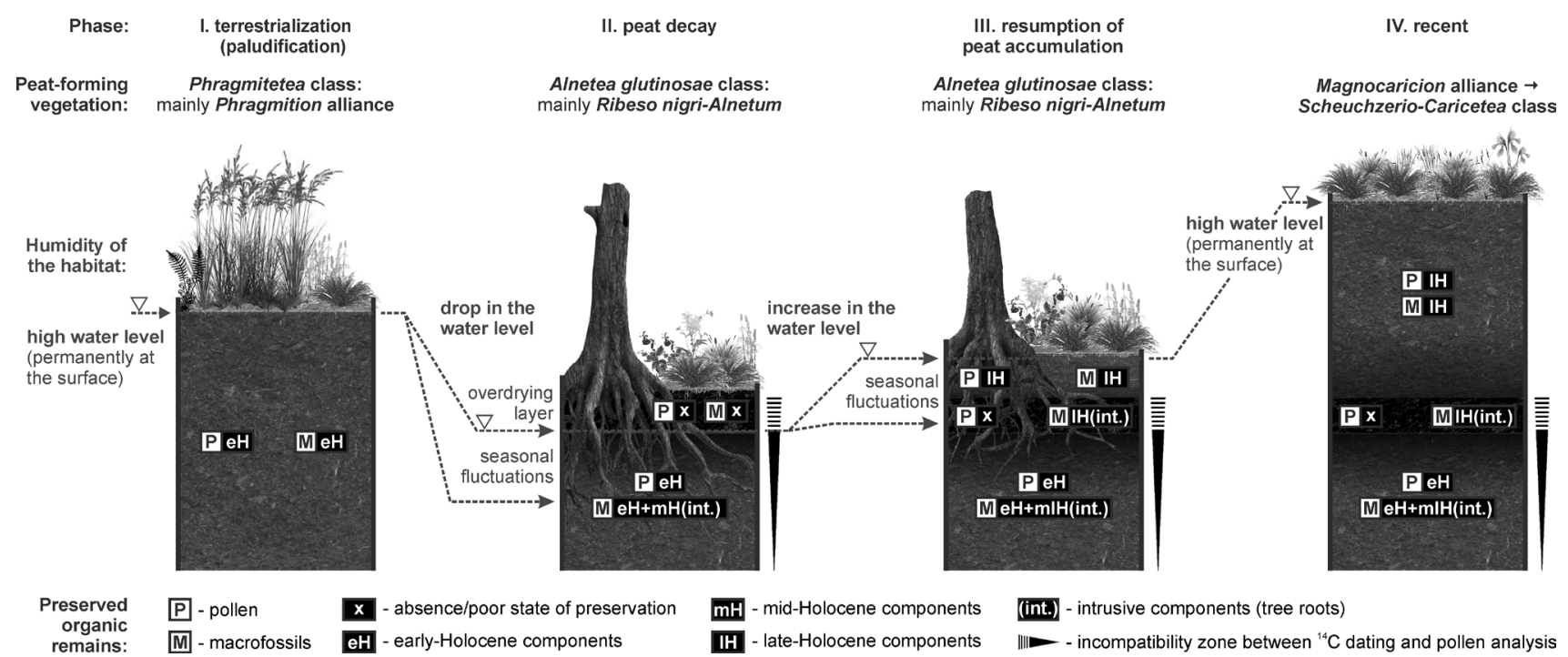

Fig. 11. Model explaining the causes of inconsistencies between ${ }^{14} \mathrm{C}$ dating and pollen analysis as a result of HSDP development. 
can be assumed that at the end of the Atlantic period, the productivity of the Ruda Kozielska mire could have been balanced. Organic matter decomposition processes were mainly synsedimentological ones and complete mineralisation of the previously accumulated peat, which would have resulted in the lowering of the mire surface, did not occur.

Radiocarbon dating of the samples that directly overlie HSDP, and in particular the application of the AMS method to the carpological remains deposited under conditions of a positive balance of productivity, should in theory enable the determination of the age at which the wet phase began in the mire in question. However, the verification of the dates obtained using pollen analysis is not an easy matter, and in some places it is ambiguous due to the absence of clear diagnostic features, sedimentation discontinuity and limited deposit thickness.

Most doubts arise in connection with the Sławięcice 1 core where the resumption of peat accumulation was dated to 350-50 cal BC using the AMS method. On the other hand, the analysis results of pollen deposits lying at that depth, e.g. high levels of Tilia cordata type pollen $(12 \%)$, suggest the Subboreal period. Correlation with the Subatlantic period - in accordance with the AMS date obtained - is also possible, since the high proportion of lime pollen may have been caused e.g. by local conditions in the vicinity of the site. On the other hand, similarly high levels of lime pollen with low shares of Carpinus, Fagus and Abies were found at the nearby Ruda Kozielska and Las Turbina (Wójcicki and Nita, 2016) sites just below the boundary between the Subboreal and Subatlantic periods. This is a fairly strong argument for correlating this part of the Sławięcice 1 core with the Subboreal period. However, even in this case the discrepancies between dating and pollen analysis results are not large. They could have been caused by a prolonged period of balanced productivity that preceded the phase in which peat accumulation resumed.

At the remaining sites, pollen analysis results appear to be broadly consistent with ${ }^{14} \mathrm{C}$ dates. In the Sławięcice 2 core, the resumption of peat accumulation occurred in the $7^{\text {th }}$ century CE according to AMS dating. In the light of pollen analysis, a correlation between the deposits examined and the Subatlantic period cannot be ruled out, e.g. on the basis of the increase in the level of Pinus sylvestris type pollen. At the Łany Małe site, the resumption of biogenic deposit accumulation was dated to $1050-790$ cal BC. The sample pollen spectrum points to the Subboreal period. The boundary between the Subboreal and Subatlantic periods within the sequence is presumably slightly higher and is represented by the decline in the levels of Tilia cordata type and Corylus avellana pollen. The low values of Carpinus, Fagus and Abies pollen recorded at the sites surveyed may be the result of overrepresentation of alder pollen. The resumption of peat accumulation in the Ruda Kozielska core occurred between $50 \mathrm{cal} \mathrm{BC}$ and cal $\mathrm{AD} 80$ according to radiocarbon dating and this is consistent with the pollen analysis results. In the light of archaeological research, the agricultural colonisation of the lower reach of the Ruda River only commenced on a large scale in the Middle Ages (Foltyn et al., 2004), which may have contributed to the subsequent appearance of crop and synanthropic plant pollen in the pollen diagram.

\section{CONCLUSIONS}

1) The studies conducted in the Racibórz Basin confirmed that fossil HSDP, which are characterised by a dark colour, a high proportion of humic substances and a decrease in the concentration and preservation levels of pollen grains, are evidence of long-term overdrying of the acrotelm layer. This is demonstrated by the presence of hiatuses, whose occurrence is indicated by sudden spikes in the pollen curves and by radiocarbon dating results that point to breaks of the order of $10^{3}$ years in the accumulation of deposits, and also by traces of peat fires in the form of charcoal and carbonaceous dust.

2) Peat cores from the Racibórz Basin contain records of wet and dry phases, which are increasingly frequently identified in the history of Central European mires. Pollen analysis demonstrates that the hiatuses cover the Atlantic period and at least partly the Subboreal one. The resumption of peat accumulation occurred in the late Holocene, although both pollen data (which point to the Subboreal or Subatlantic period at individual sites) and radiocarbon dating (ranging from 1050-790 cal BC to cal AD 600-680) appear to indicate that the process was not synchronous.

3) In the light of the results obtained, it appears that the condition for HSDP development was the simultaneous presence of endogenous (the advanced development stage of mires with forest communities of the Alnetea glutinosae class) and exogenous factors (the decrease in habitat humidity, probably caused by climate conditions). The resumption of peat accumulation occurred under conditions of elevated groundwater levels, which were caused by exogenous factors (a more humid climate and/or changes in surface runoff as a result of agricultural activity in the catchment). This was evidenced by the development of non-forest, sedge-moss communities belonging to the Magnocaricion alliance or the ScheuchzerioCaricetea nigrae class.

4) The dating of phases with a negative balance of mire productivity should be approached with caution, since HSDP contain organic matter of different ages. Studies have shown that in the case of postsedimentological peat decay involving ever deeper peat layers, ${ }^{14} \mathrm{C}$ dates differ significantly from the chronozones determined using palynological methods. This indicates that when determining the age of 
dry phases, the dating of pollen, carpological finds or above-ground vegetation remains (e.g. mosses) is not useful since they could have been preserved from the earlier phases of mire development. The dating of intrusive wood enables the determination of the development age of the forest formation, which, however, is not necessarily the same as the HSDP development age.

5) The correlation between pollen analysis and ${ }^{14} \mathrm{C}$ dating results indicates that it is possible to reliably determine the age of the boundary between dry and wet phases in mires.

\section{ACKNOWLEDGMENTS}

The publication has been partially financed from the funds of the Leading National Research Centre (KNOW) received by the Centre for Polar Studies of the University of Silesia, Poland.

\section{REFERENCES}

Abłamowicz D and Śnieszko Z, 2001. Osadnictwo kultur rolniczych w dorzeczu środkowej Kłodnicy a atrakcyjność krajobrazu (Farming settlement in the middle basin of the Kłodnica River and the landscape attractiveness). Sprawozdania archeologiczne 53: 35-83 (in Polish).

Bronk Ramsey C, 2009. Bayesian analysis of radiocarbon dates. Radiocarbon 51: 337-360.

Caspers G and Grosse-Brauckmann G, 2003. Paleoecological investigations in the fen Pestruper Moor (district Oldenburg) in view of the history of the river Hunte since the Weichselian Late Glacial. Telma 33: 21-34.

Faegri K and Iversen J, 1978. Podręcznik do analizy pytkowej (Textbook of pollen analysis). Wydawnictwa Geologiczne, Warszawa: 249 pp (in Polish).

Foltyn EM, Foltyn E and Waga M, 2004. Przemiany osadnictwa w dorzeczu Rudy w dobie gospodarki rolno-hodowlanej (od neolitu po wczesne średniowiecze) (Settlement changes in the Ruda Basin in the period of farming and animal breeding economy (from Neolithic to early Middle Ages)). In: Abłamowicz D and Śnieszko Z, eds., Zmiany środowiska geograficznego $w$ dobie gospodarki rolno-hodowlanej. Studia z obszaru Polski. Katowice: 293-314 (in Polish).

Forysiak J, 2012. Zapis zmian środowiska przyrodniczego poźnego vistulianu i holocenu $\mathrm{w}$ osadach torfowisk regionu łódzkiego (Record of changes in the natural environment of the Late Weichselian and Holocene preserved in the sediment of peatlands of the Łódź Region). Acta Geographica Lodziensia 99: 5-164 (in Polish).

Forysiak J, Kloss M, Obremska M and Żurek S, 2014. Późnoglacjalne i holoceńskie osady wybranych torfowisk dolinnych regionu łódzkiego w nawiązaniu do zmian paleośrodowiskowych (Lateglacial and Holocene sediments of some valley peatlands in the Łodź Region in relation to palaeoenvironmental changes). Folia Quaternaria 82: 5-30 (in Polish).

Grosse-Brauckmann G, 1986. Analysis of vegetative plant macrofossils. In: Berglund BE, ed., Handbook of Holocene Palaeoecology and Palaeohydrology. John Wiley and Sons, Chichester: 591-618.

Harmata K, 1987. Late-glacial and Holocene history of vegetation at Roztoki and Tarnowiec near Jasło (Jasło-Sanok Depression). Acta Palaeobotanica 27(1): 43-65.

Harmata K, 1995. A Late Glacial and early Holocene profile from Jasło and a recapitulation of the studies on the vegetational history of the Jasło-Sanok Depression in the last 13000 years. Acta Palaeobotanica 35(1): 15-45.
Kalicki T and Zernickaya VP, 1995. Paleogeography of the Vistula valley near Cracow based on sediments and palynology of the Allerød paleochannel fill. In: Starkel L, ed., Evolution of the Vistula River valley during the last 15000 years. Part V. Geographical Studies, Special Issue 8: 9-18.

Kloss M, 2007. Roślinność subfosylna na tle historii wysokich torfowisk maszarnych $w$ pólnocno-wschodniej $i$ środkowej Polsce oraz $w$ Sudetach (Subfossil vegetation in the light of history of sphagnum raised mires in the north-eastern and central Poland as well as in the Sudety Mountains). Instytut Badawczy Leśnictwa, Sękocin Stary: $141 \mathrm{pp}$ (in Polish).

Kloss M and Żurek S, 2005. Geology of raised mires deposits. Monographiae Botanicae 94: 65-80.

Kołodziejczyk K, 2013. Analiza makroszczatków roślinnych jako podstawa oceny degradacji torfowisk użytkowanych rolniczo (Plant macrofossil analysis as the basis for evaluation of degradation of agriculturally used peatlands). PhD Thesis. University of Environmental and Live Science, Wrocław: 237 pp (in Polish).

Kondracki J, 1998. Geografia regionalna Polski (Regional geography of Poland). Wydawnictwo Naukowe PWN, Warszawa: 441 pp (in Polish).

Ludwikowska-Kẹdzia M, 2000. Ewolucja środkowego odcinka doliny rzeki Belnianki w późnym glacjale i holocenie (Evolution of the middle reach of the Belnianka River valley in the Lateglacial and Holocene). Wydawnictwo Akademickie Dialog, Warszawa: 181 pp (in Polish).

Magny M, Begeot C, Guiot J and Peyron O, 2003. Contrasting patterns of hydrological changes in Europe in response to Holocene climate cooling phases. Quaternary Science Reviews 22: 1589-1596, DOI 10.1016/S0277-3791(03)00131-8.

Marek S, 1965. Biologia i stratygrafia torfowisk olszynowych w Polsce (Biology and stratigraphy of alder peatlands in Poland). Zeszyty problemowe postępów nauk rolniczych 57: 5-265 (in Polish).

Matuszkiewicz W, 2005. Przewodnik do oznaczania zbiorowisk roślinnych Polski (A guidebook for identification of Polish plant associations). Wyd. Naukowe PWN, Warszawa: 537 pp (in Polish).

Nita M and Wójcicki K, 2005. Record of Holocene vegetation changes against a background of environmental conditions in the Kłodnica valley (southern Poland). Quaestiones Geographicae 24: 63-73.

Okruszko H and Ilnicki P, 2003. The Moorsh Horizons as Quality Indicators of Reclaimed Organic Soils. In: Parent LE and Ilnicki P, eds., Organic Soils and Peat Materials for Sustainable Agriculture. CRC Press LLC, Boca Raton-London-New YorkWashington, D.C.: 1-14.

Ralska-Jasiewiczowa M and Starkel L, 1988. Record of the hydrological changes during the Holocene in the lake, mire and fluvial deposits of Poland. Folia Quaternaria 57: 91-127.

Reimer PJ, Bard E, Bayliss A, Beck JW, Blackwell PG, Bronk Ramsey C, Grootes PM, Guilderson TP, Haflidason H, Hajdas I, Hatt C, Heaton TJ, Hoffmann DL, Hogg AG, Hughen KA, Kaiser KF, Kromer B, Manning SW, Niu M, Reimer RW, Richards DA, Scott EM, Southon JR, Staff RA, Turney CSM and van der Plicht J, 2013. IntCal13 and Marine13 Radiocarbon Age Calibration Curves 0-50,000 Years cal BP. Radiocarbon 55(4): 1869-1887.

Rybníček K and Rybníčkova E, 1987. Palaeogeobotanical evidence of middle Holocene stratigraphic hiatuses in Czechoslovakia and their explanation. Folia Geobotanica et Phytotaxonomica 22(3): 313-327.

System Informacji Przestrzennej o Mokradłach Polski (GIS "Wetlands of Poland"), 2006. Instytut Melioracji i Użytków Zielonych, Falenty (in Polish).

Szczepanek K, 1982. Development of the peat-bog at Słopiec and the vegetational history of the Świętokrzyskie (Holy Cross) Mts in the last 10000 years. Acta Palaeobotanica 22(1): 117-130.

Tobolski K, 2000. Przewodnik do oznaczania torfów i osadów jeziornych (A guidebook for identification of peat and lacustrine deposits). Wydawnictwo Naukowe PWN, Warszawa: 508 pp (in Polish).

Tobolski K, 2003. Torfowiska na przykładzie Ziemi Świeckiej (Mires on example of the Świecie Region). Towarzystwo Przyjaciół Dolnej Wisły, Świecie: 255 pp (in Polish). 
Tomaszewska K and Kołodziejczyk K, 2010. Możliwości identyfikacji makroszczątków roślinnych w profilu murszowo-torfowym wskazujących na degradację ekosystemu bagiennego (The possibility of indentification of plant macro-remains in peat-moorsh profile indicating degradation of the wetland ecosystem). Woda-ŚrodowiskoObszary Wiejskie 10(3): 309-319 (in Polish).

Wójcicki KJ, 2000. Późnovistuliańska i holoceńska transformacja dolin wybranych dopływów górnej Odry na podstawie analizy paleokoryt i wypełniających je osadów (The late-Vistulian and Holocene evolution of the selected valleys in the Upper Odra Basin based on the analysis of palaeochannels and their deposits). PhD Thesis. University of Silesia, Katowice: 122 pp (in Polish).

Wójcicki KJ, 2013. Osady biogeniczne w środowisku depozycyjnym starorzeczy (Biogenic sediments in abondoned river channels). Wyd. UŚ, Katowice: 239 pp (in Polish).

Wójcicki KJ and Kloss M, 2008. Makroszczątki roślinne w torfie w analizie paleośrodowiskowych uwarunkowań osadnictwa na przykładzie stanowiska Łany Małe w dolinie Kłodnicy (Peat macrofossils in the analysis of palaeoenvironmental conditions of settlement; the case of Łany Małe site in the Kłodnica valley).
Studia Ecologiae et Bioethicae 6: 449-460 (in Polish).

Wójcicki KJ and Nita M, 2016. Holoceńska historia roślinności siedlisk mokradłowych w dolinach rzecznych dorzecza górnej Odry (Holocene vegetation history of wetland habitats in the river valleys of the upper Odra River basin). Acta Geographica Lodziensia 105: 93-105 (in Polish).

Wójcicki KJ, Śleszyński P and Mazur S, 2010. Holocene inset fills of the Odra River in the Racibórz Basin. Quaestiones Geographicae 29(3): 85-93.

Żurek S and Pazdur A, 1999. Zapis zmian paleohydrologicznych w rozwoju torfowisk Polski (Record of palaeohydrological changes in development of mires in Poland). In: Pazdur A, Bluszcz A, Stankowski W and Starkel L, eds., Geochronologia górnego czwartorzędu Polski w świetle datowania radioweglowego i luminescencyjnego: Tinta, Wrocław: 215-228 (in Polish).

Żurek S, Michczyńska DJ and Pazdur A, 2002. Time record of palaeohydrologic changes in the development of mires during the Late Glacial and Holocene, North Podlasie Lowland and Holy Cross Mts. Geochronometria 21: 109-118. 